\title{
Dimensions of the work of the nurse in the hospital setting*
}

\author{
Dimensões do trabalho do enfermeiro no contexto hospitalar \\ Dimensiones del trabajo de enfermería en el ámbito hospitalario
}

\author{
Giovanna Valim Presotto ${ }^{1}$, Maria Beatriz Guimarães Ferreira² ${ }^{2}$ Divanice Contim³ ${ }^{3}$ Ana Lúcia de Assis Simões ${ }^{3}$
}

This research aimed at understanding the perception of nurses concerning the dimensions of work in the daily activities of a university hospital. It is a descriptive, exploratory and qualitative study made with 19 nurses working in a Federal University Hospital in Minas Gerais, Brazil. Data were collected in August and September 2010, through interviews, and submitted to content analysis. The results showed four distinct dimensions: aspects related to human care, to the management of care and service, to the permanent education and to the need to produce and make use of the results of the research. It is concluded that nurses recognize the extent of their work and their interfaces in the hospital setting. The study of aspects related to the work process can contribute to the construction of the identity of the nurse and the strengthening of the profession.

Descriptors: Organization and Administration; Nursing Service, Hospital; Working Conditions; Nursing.

Esta pesquisa teve como objetivo compreender a percepção dos enfermeiros sobre as dimensões do trabalho que realizam no cotidiano de um hospital universitário. Trata-se de estudo descritivo-exploratório, qualitativo, realizado com 19 enfermeiros que atuavam em um hospital da rede federal de ensino do interior de Minas Gerais, Brasil. Os dados foram coletados nos meses de agosto e setembro de 2010, por meio de entrevistas, e submetidos à análise de conteúdo. Os resultados evidenciaram quatro dimensões distintas: aspectos relacionados ao cuidado humano, à gerência do cuidado e do serviço, à educação permanente e à necessidade de produzir e de consumir resultados de pesquisa. Concluiu-se que os enfermeiros reconhecem a amplitude de sua atuação e as interfaces do seu trabalho no cenário hospitalar. 0 estudo dos aspectos relacionados ao processo de trabalho pode contribuir na construção da identidade do enfermeiro e no fortalecimento da profissão.

Descritores: Organização e Administração; Serviço Hospitalar de Enfermagem; Condições de Trabalho; Enfermagem.

El objetivo de la investigación fue comprender la percepción de enfermeros sobre las dimensiones del trabajo que realizan en la rutina de un hospital universitario. Estudio descriptivo, exploratorio, cualitativo, llevado a cabo con 19 enfermeros que trabajaban en un hospital federal de Minas Gerais, Brasil. Los datos se recopilaron en agosto y septiembre de 2010, a través de entrevistas, y se sometieron a análisis de contenido. Los resultados señalaron cuatro dimensiones: aspectos relacionados a la atención humana, a la gestión de la atención y del servicio, a la educación permanente y a la necesidad de producir y de consumir resultados de investigación. En conclusión, los enfermeros reconocieron la amplitud de su actuación y las interfaces del trabajo en el ámbito hospitalario. El estudio de los aspectos relacionados con el proceso de trabajo puede contribuir a la construcción de la identidad del enfermero y en el fortalecimiento de la profesión.

Descriptores: Organización y Administración; Servicio de Enfermería en Hospital; Condiciones de Trabajo; Enfermería.

\footnotetext{
*Article taken from the paper 'The Process of the work of the nurse in the hospital setting', presented at the Program of Post-Graduation Scricto Sensu in attention to health, Universidade Federal do Triângulo Mineiro, Minas Gerais, Brazil, 2011.

${ }^{1}$ Hospital de Clínicas, Universidade Federal do Triângulo Mineiro. Uberaba, MG, Brazil.

${ }^{2}$ Escola de Enfermagem de Ribeirão Preto, Universidade de São Paulo. Ribeirão Preto, SP, Brazil.

${ }^{3}$ Universidade Federal do Triângulo Mineiro. Uberaba, MG, Brazil.

Corresponding author: Ana Lúcia de Assis Simões

Rua Dona Nitinha, 181; Bairro Estados Unidos. CEP: 38017-300. Uberaba, MG, Brazil. E-mail: ana.assis@reitoria.uftm.edu.br
} 


\section{Introduction}

The process of work consists of the interaction among the need of the human being, production and consumption, in which the man transforms an object, originating a product. The products of a work can be concrete goods, that is, material elements that can be perceived by the organs of the senses, or services, which are perceived through the effect that they cause ${ }^{(1)}$.

Concerning health, this process produces services, whose use happens during the production, that is, at the moment of the nursing care $^{(2)}$. In the hospital setting, the nurse has worked with priority in the dimensions of the process of nursing work, configured in assistance, managerial, educational and of research. These dimensions must articulate among themselves in an inseparably way ${ }^{(3)}$.

In the assistance dimension, the need of nursing care required by the patient is characterized as object of work, with the purpose of promoting a quality, whole and ethic ${ }^{(2-4)}$. The managerial dimension is focused in the organization of the work and in the material, physical and human resources of nursing, with the purpose to adequate the conditions for an organized, safe and quality assistance $\mathrm{e}^{(2-4)}$.

The teaching dimension contemplates both the academic perspective involving students and professors, as well as the assistance perspective, with the nurses and nursing technicians, through the permanent educations at work. In the hospital scope, the object of teaching consists of the subjects who need to acquire knowledge, abilities and attitudes through methods and resources of teaching-learning, aiming at improving the development and the professional competence, in order to minimize the problems derived from the education, and also to reach satisfactory levels of the quality of the assistance ${ }^{(3-5)}$.

In turn, the dimension researched has as objective the knowledge and its gaps, with the purpose of discovering new and improved forms of acting on the working process. The products of this sub process are new knowledge, which can be used to understand and modify the work ${ }^{(3-4)}$. Such dimension present a direct relation with the Practice Based on Evidence, which states that the incorporation of results of researches to the clinical practice can provide the increase of the quality of the health care and the improvement of the results of the patients ${ }^{(6)}$.

These dimensions are inter-related in a simultaneous way or complementing actions related to the care of the subject, developing a set of activities turned to the process of nursing work $^{(2,4)}$.

It is opportune to highlight that the attributions of the nursing team (nurses, technicians and nursing assistants) comply with the Law of the Professional Exercise $^{(7)}$, which provides the division of the work, with the consequent fragmentation of care. In this model of organization, the nurse renders assistance to the patients who demand intensive care; he manages the nursing services and also coordinates the other cares mostly rendered by technicians and nursing assistants.

In the social-historical-political context, the nurse elaborates and organizes the work whether it is of technical or political nature, directing the assistance of the needs generated by society ${ }^{(2-3)}$.

Facing these considerations, the following question arrives: how do the nurses perceive the dimensions of the work they perform in the daily activities of a university hospital?

It becomes relevant to know the dimensions of the work of the nurse in the hospital setting, glimpsing the comprehension of what is effectively being developed by this professional. It is also highlighted the importance of making a study on the dimensions of the working process of the nurse, keeping in mind the excess of functions incorporated to the labor routine. It is expected to have a contribution to better delineate the domain of the nurse, their functions and responsibilities.

For such, this study has the objective to understand the perception of the nurses on the dimensions of the work they perform in the daily activities of a university hospital. 


\section{Method}

It is a descriptive exploratory study of qualitative approach, made in a federal teaching university hospital, located in Uberaba, MG, Brazil, of regional reference, which renders assistance of high complexity in the scope of the Unified Health System.

The subjects of the research were assistance nurses, placed in several units of hospitalization, who worked in the morning, afternoon and night shifts. The criterion of inclusion was to have been working in the institution for more than one year, time considered sufficient for the integration of the health professional to the institution. The simple random sampling was used in order to choose the interviewed nurses, as well as the units observed. The interviews were made until data saturation.

The data collection was made in August and September, 2010, at a venue and time chosen by the subjects, who accepted to participate in the study, after the signing of the Free Informed Consent Form, thus guaranteeing confidentiality of the information supplied.

The statements were obtained through semi-structured interviews, digitally recorded. The interview was guided by the following questions: Describe your daily routine of work. In your opinion, what justifies the execution of those activities? Of the mentioned activities, which ones do you consider priority? When evaluating the work you develop along a journey, do you believe that other activities should/ could be developed and which are not? If so, which activities these would be and which reasons have prevented their execution?

Considering the nature of the study, the number of participants was not previously defined, and the data collection was closed when there were signs of saturation, that is, the moment in which there was no new information on the phenomenon under study and also when the concerns of the researches were answered and the objectives reached ${ }^{(8)}$.

The information was completely transcript and exhaustively read, the data were submitted to the analysis of content ${ }^{(9)}$, respecting the three proposed phases: pre-analysis, exploration of the material and treatment and interpretation of the data obtained. The statements were cut in units of register, which were codified, quantified and afterwards, grouped by convergence of meanings. The following step was categorization, where four theme categories emerged: Assistance dimension in the work of the nurse, Administrative dimension in the work of the nurse, Educative dimension in the work of the nurse and Dimension of research in the work of the nurse.

The research was approved by the Committee of Ethics and Research with Human Beings of the Universidade Federal do Triângulo Mineiro, MG, Brazil (Legal opinion no. 1626/2010). In order to have anonymity of the subjects, the letter $\mathrm{E}$ was attributed to each one followed by the number of the interview.

\section{Results}

\section{Characteristics of the population of the study}

The protagonists of the study were 19 nurses predominantly female and young adult. The average age was 34.7 years. The average time of work in the institution was 6.57 years. Concerning the time of graduation the average was 9.35 years. Regarding the professional qualification, four were graduated, 14 were specialists and one had post-graduation degree Stricto Sensu, the master's degree. As to the link with the institution, 11 were linked to the Unified Legal Regime of the Country and 14 had more than one job. Concerning the sectors of work, the study involved nurses placed in the Intensive Therapy Unit, Unit of infectious and Parasitic Diseases, Gynecology and Obstetrics, Nursery, Medical Clinic, Surgical Clinic, Adult Emergency Room, Child Emergency Room, Pediatrics, Neurology and Orthopedics.

From the analysis of the material collected, 248 units of register were identified, which were grouped into four categories presented as follows. 


\section{Assistance dimension in the work of the nurse}

The perception of the nurses on the activities which characterize assistance identified actions which aim at assuring the quality of the nursing assistance, as exemplified in the statement as follows: At the moment I arrived, I have to recognize the patients. I go there to see how they are, what kind of patient there is in the sector, how they are, how I am receiving ... (E17).

The nurses when developing assistance practice see the legislation as a legal and ethical support for their actions, as the following statements show: I do assistance activity which is exclusive of the nurse such as naso-enteral probe, jugular puncture and evolution of nursing in the case of the Intensive Therapy Center - Adult Emergency Room. I assist the serious patient in exams and transferences. I render nursing assistance to serious patients and also not serious... (E19). ... We make the transportation of the patient, because here the patients are not transported without the help of the nurse, we help in more complicated procedures, for example, intubation... extubation... punctures and probing... (E2).

When they feel responsible for the direct care of the patient in a serious condition, the nurses highlight the stablishing of the therapeutic alliance as a collaborating factor for the integrality of the care, considering it as the central focus of their work, as the following statement expresses: The direct assistance to the patient is priority. The nurse has a differentiated look, many times the patient has more confidence in the nurse to expose his anxiety and doubts, and for example, concerning medication, many times the nurse provides the necessary orientation (E3).

In the scenario of this reality of the assistance practice, the intention of implanting the Systematization of the Nursing Assistance can be perceived in the following statements: The systematization of the assistance is what we crave, starting now with the evolutions (E4)... I start doing the physical examination of all the children, the ones who are hospitalized in odd beds, I make the nursing evolutions and, after those nursing evolutions, I write the nursing care which must be taken with this child... (E4).

\section{Administrative dimension in the work of the nurse}

The statements of the interviewed nurses allowed highlighting distinct aspects related to the administrative functions in the daily activities of work, concerning the activities performed in the exercise of management. They registered the concern with the work team: ... the first thing I do is to organize the distribution of the workers in the Emergency Room... (E8). I arrive at the sector and I check if there weren't absences; if there were I redistribute the workers... (E16).

The statement explained in: I do this routine, this planning like; more mental, not all nurses do this... (E10) is concerning the planning, in essential instrument of the process of management of the organization, which allows analyzing the problems and qualifying the taking of decision.

The meetings constitute a concrete manner for the adequacy of a common assistance project, characterized by the organization of the work. An aspect which is confirmed by the nurses when they state: ... I have weekly meetings with all of them to provide general orientation (E5).... pass the information to the technician in a meeting, especially when there is some orientation, I pass it on to the technicians and write in a specific notebook... (E18).

The forecast of the quantity and quality of the material used at the unit is one of the managerial actions taken by the nurse. This is highlighted in the statement as follows: ... I control the material, the equipment, all those things... (E14).... I request things from the warehouse, because we sign, I check everything... (E13).

The organization of the daily work, shown by the environment or by the quality and adequacy of the materials was mentioned by the nurses: ... soon after that, I check if the emergency cart is sealed, and if the seal is equal to the seal that is described in the notebook, if the oxygen cylinder is full, the whole organization of the sector... (E6). ... I check the situation of the emergency room and the equipment... (E1). 


\section{Educative dimension in the work of the nurse}

In this study, the education in health is identified as a relative attribution to the directing of the professionals in the daily activities of work, while proving assistance, in order to clarify doubts on procedures and techniques as well as the orientation of family members concerning the clinical condition of the patients. At the time of discharge we have to teach, orient the patient or a person of the family concerning the continuity of the treatment at home... (E17). I have to look at everything from the moment of admission of the patient... I have to pass on the information on the hospitalization... I have to teach how the hospital works... talk about the measures to keep the place clean and safe (E15).

The nurses also understand the Continued Education as a process of transformation of the institution through the capacitation and development, showing concern with a quality of the assistance rendered by the nursing team, concerning the clarification of doubts, performing updating and capacitation, as well as the assistance of the activities performed by the technical and assistant personal, when they state:... I wanted to teach more in the service with the workers, to follow closely and see how they are developing certain activities, if they are doing the correct technique, to provide some orientation... (E14).

\section{Dimension of research in the work of the nurse}

The nurse who acts in different practices of the process of work faces the needs to produce and consume products of research, thus subsidizing the process of care. It is highlighted that this process must make in an integrated and concomitant manner. So, such dynamics produces new knowledge or ways of doing and/or investigating, showing itself at the same time favorable or adverse, in this context. This need is described by the statement of a participant: The nurse, besides providing assistance, should also provide updating, this is a scientific progress. Because the nurse stays a long time in the assistance area and knows the practice, and the professors keep the scientific knowledge, the union of this part would be a good opportunity to develop scientific articles, promote the improvement of the assistance and of the teaching. I observe that there is a distance between the professors and the nurses of the hospital. It's necessary to improve, enhance the domain of vision, to see things from a different angle (E12).

Another factor is the integration between professors and assistance professionals, in order to invigorate teaching through activities of field investigation, when highlighting the importance of the research in the following statement: ... another thing that I think it's very important, it would be if you were doing some work, making some research, because the sector is very rich... (E13).

\section{Discussion}

The characteristic of the nursing work is guided by human care, based on science and technology. The assistance activities are performed from the thorough perspective of the human being dependent of care which, articulated with other systematized actions, make the nursing work easier. At the hospital institutions, the nursing actions require theoretical and practical knowledge in order to base and enable the development of the activities, once they are characterized by different levels of complexity ${ }^{(10)}$.

In the process of work in nursing, the responsibilities goes beyond the assistance, that is, the actions of management comprise the organization and the planning of physical, human, material resources and the structuring with the purpose to obtain adequate conditions of assistance and work. According to that, the attributions of responsibility of the nurse are relevant for the qualification of assistance to the subjects ${ }^{(2)}$.

The priority in the process of assistance work has as action the therapeutic care, which consists of direct or indirect care, contextualized in each situation, aiming at satisfying the need of the subject, having in the therapeutic perspective the nursing assistance as a priority in the process of work ${ }^{(10)}$. The assistance action refers to the care of the team and the subjects who need it, and it is fundamental to have the recognition of the work as a necessary focus to be managed in the institutions of health, in order to extrapolate 
the technique and incorporate the knowledge and the attitudes in a rational manner that those transit from sense to sensibility ${ }^{(4,11)}$.

It is worth registering that the promulgation of Law no. 7498/1986, which provides the regulation of the Exercise of Nursing in Brazil, is that the private right of the nurse to the activities concerning the: 'planning, organization, coordination, execution and evaluation of the nursing assistance services' was legally formalized, that is, of the administrative or managerial process of these service ${ }^{(7)}$.

Among the assistance activities developed, it is observed that the nurses report that they dedicate themselves to the performance of procedures especially the ones considered of higher technical complexity, such as dressing, probing and venous punctures.

When reporting that the priority is care in its elementary form, the subjects express the concern to render a good assistance to the patient through the direct supervision of his team, guaranteeing that the work is executed the best possible manner. For that the nurse needs to use all the scientific knowledge acquired along his education. So that this process can be effective, it becomes necessary to have the development of competences and abilities, aiming at a differentiated complete and holistic care in the real sense of the word ${ }^{(2,4,10,12)}$.

In this study the nurses include the Systematization of Assistance of Nursing, based in complying with the legal principles of the profession and improve the assistance. This process requires professional competence of the nurses. So, Systematization of Assistance of Nursing needs to extrapolate the limits of disciplinary knowledge and go on in the dialogic and complementary perspective towards the other health professionals, considering the need of interdisciplinary work, the continuity of care and the connectivity of the practices of health ${ }^{(12)}$.

The Resolution of the Federal Counsel of Nursing no. $272 / 2002$, in its article $2^{\text {nd }}$ affirms that: 'the implementation of the Systematization of the Assistance of Nursing must occur in every institution of health, public or private' ${ }^{\prime(13)}$. Even with the effort of the Counsel and the whole professional class, it is knowledge that despite having been introduced in Brazil in the 70 decade, still presents a huge gap between the production of knowledge and its applicability in the daily practice of the nurse ${ }^{(12)}$.

The use of this method of work requires the critical and scientific thought of the nurse, focused in objectives and targets aiming at the positive results in order to assist the needs of the patient and his family; it requires constant updating, abilities and experience, oriented by the ethics and the standards of behavior. The Systematization of the Assistance of Nursing offers aids for the development of interdisciplinary and harmonized methodologies of care. Researches made on this theme highlight that this methodology provides an improvement of the assistance quality, more efficiency, autonomy and scientific approach, as well as the need of research and its knowledge in the scenario of services of health ${ }^{(12,14)}$.

The formalization of their attributions, associated to the role played by the nurse and the organizations of health, determines that he should be responsible for the administration of nursing assistance. This prerogative grants to the nurse the responsibility of taking decisions, requiring its fulfillment in order to concatenate with the objectives and the use of resources of the organization. So, it is possible to state that the administration of assistance of nursing is materialized in one manager: the nurse $\mathrm{e}^{(2)}$.

The comprehension of the process of work and the administration in the hospital context made by nurses is indispensable in the daily activities of the hospital organizations, whose major purpose is to offer an adequate assistance of nursing to the patient and to the society. It is worth highlighting that this exercise is a challenging activity. Nowadays, this process is subsidized by different theories which permeate the necessary reformulations to the adaptation of the constant instabilities in the market and in the world. The administration in nursing is mentioned by several authors as the activity which has had the gre- 
atest development in the practice of the nurses, with implications for the quality of assistance as well(10-11,15).

In this context, the process of administering in nursing has as the center of its attention the user, oriented for the assistance which involves planning, direction, supervision and evaluation of the activities developed by the nursing team, aiming at the assistance of the needs of this clientele ${ }^{(5,10-11)}$.

Results related to planning report that in an environment of work where there is no structured planning of the activities and determination of priorities, there is a significant loss of time in the process of management, leading the professionals to redo the activities performed without success ${ }^{(5,10-11,16)}$.

The experience of the nurse who acts in the hospital service is manifested by attitude, values and standards of behavior in the development in the activities which involve the process of administrating, defining the actions to be implemented by the team. With the planning the nurse unleashes the other fundamental functions of management, that is, the possibility of coordinate, control and evaluate the performance of the team facing the practice and social organization, thus observing attitude and postures which characterize the health professionals ${ }^{(5,11,15-17)}$.

The planning of the assistance of nursing aims at defining the actions to be implemented in advance, by the team, having the objective to reach their targets facing the needs of the patients/clients ${ }^{(16-17)}$.

In the planning of daily activities, the nurses elaborate administrative and operational instruments, in order to obtain an effective performance of their process of work ${ }^{(16)}$. These instruments point at the effectiveness of management of the care of nursing and of the care in health. The elaboration of the daily distribution of the workers was highlighted among the managerial activities of the nurses. This distribution among the sectors is always subject to modification, once the nursing professionals can be moved from one area to another, according to the increase or decrease of the number of patients along one shift of work ${ }^{(16)}$.

In the daily practice of the nurses, the distribu- tion of the staff is made empirically, in order to depend on the professional experience when evaluating the gravity and the load of the work of nursing required by the patient, grounded on the clinical instability of the patient and on the therapeutic procedures to be made, in order to avoid the overload of work of the professionals and ensure the quality of assistance ${ }^{(16-18)}$.

The nurses are responsible, among other activities, by the management of care, which involves the management of resources and the coordination and articulation of the work of the nursing team and the supervision of the technical and institutional functions ${ }^{(17-18)}$. So that this process can be effective, the communication and integration among the agents involved is necessary, in order to have consensus and agreements. The nurse manages the care when he plans it, delegates it or performs it, when he also interacts with the nursing team and with other professionals, occupying areas of articulation and negotiation in favor of the consecution of improvement of care $^{(2,5,11,16-18)}$, requiring from the subject the adoption of a participative attitude when interacting with the team and taking decisions, without imposing power, valuing the team work and leadership ${ }^{(2,5,11,17)}$. The harmonious organizational environments, with satisfactory professional relation which allows cooperation and trust between the management and the subordinates and subordinates among themselves, favoring the overcoming of barriers imposed by the work and the construction of strategies of defense which will allow the continuity of the productive process ${ }^{(19)}$.

It should also be added, that in this same scenario, the nurse faces functions related to the administration of material resources, aiming at the forecast and provision of resources for the production of care, one of the reasons of concern in the organizations of health, both in the public as well as in the private sector.

The management of material resources in the assistance of nursing is an administrative process which involves the taking of decision, in the search for efficiency of the use of the available inputs, respecting 
both the needs of the clientele as well as the institutional purposes ${ }^{(20)}$. The nursing team is the greater user of material resources in the assistance in health and the management control of the nurse involves several measures: quantitative and qualitative determination of the material necessary to assistance, control and evaluation of the material, participation in the process of buying, assistance of the profile of consumption, process of communication stablished with the workers for the orientation of the rational use, adequacy of cost benefits of the physical areas and of the material resources ${ }^{(5,10-11,16,19)}$.

In this context, it is up to them to search for means to guarantee availability and quality of the material and infrastructure resources, providing the team a better performance in the assistance to situations of urgency, facing the needs of the patients, in order to conciliate the organizational objectives and the objectives of the nursing team aiming at a better quality of assistance rendered ${ }^{(5,10-11,18-19)}$.

When using the administrative knowledge and his practice, the nurse manages the unit and the care, which also involves the taking of decision, the supervision and the leadership of the nursing team ${ }^{(2,10-11,19)}$. So, the objects of acting of the nurse in the managerial process are the organization of the work and of the resources which are necessary to its operationalization.

The educative dimension in the work of the nurse is one of the fundamental axes, which drives and qualifies the practices, enabling the following factors: transform hegemonic conceptions of the health-disease process, update practices, reformulate public and social policies, know and understand the dynamics of local needs in health and restructure or orient the process of decision of the sector of management in health ${ }^{(20-21)}$.

The educative process involves themes such as: education in basic attention to the population, permanent education of the health professionals, education technologies in health, teaching learning process, critical and participative evaluation in the professionalizing courses, graduation and post-graduation, as well as the participation of the nurses in the stages supervised by the academic group, collaborating in the formal processes of teaching ${ }^{(21-22)}$.

The choice of the pedagogical conception is fundamental in education in health to propitiate to the user with the possibility of criticism and elaboration of the knowledge, providing significant learning for the people. The educative actions made are effective instrument for the education of a critical knowledge, enabling the comprehension of subjects and their autonomy facing the conditions of life and health. Researches had reinforced the importance of the strategies which promote the behavioral changes adapted to the social cultural context and to the style of life of the users of the services of health, as well as a gradual and permanent responsibility ${ }^{(20-21)}$.

The education of the health professionals and the initiatives of continuous capacitation have been characterized by the relation with the process of institutional work, aiming at the transformation of the practice. For such, the discussion of the reality has been adopted as a pedagogical presupposition, from the elements that make sense for the responsible professionals, which is aimed at improving the conditions of work and of the quality of the services ${ }^{(20-21)}$.

The assistance area is privileged by the richness of phenomena that emerges as objects as studies, allowing several possibilities of research with the use of different methods, contributing for the consolidation of nursing as social practice ${ }^{(23)}$. It is highlighted that the nurse, in the everyday activities of work has possibilities of making researches in loco, articulating researches and professional practices.

It is understood that the assistant based on conclusions generated by studies conducted by strict scientific methods, is considered gold standard in the care of health, for providing better quality of assistance minimizing cost due to the reduction of morbidity/mortality in medical errors, as well as promoting standards of safety and reliability to the health organizations $^{(24)}$. Despite the fact that the practice based on evidence provides benefits for the patients, for 
the health system and for the health professionals, the scholars show barriers for the implementation of this approach in health ${ }^{(25)}$. A study made with North-American nurses questioned the factors which impeded them to implement results of research in the daily practice, which reported lack of time, organizational culture, abilities and knowledge on Practice Based on Evidence and the lack of access to the evidence as well as the resistance of the leader/manager ${ }^{(25)}$.

It worth highlighting that the dimension research, inserted in the process of work of the nurse, requires the learning of new abilities for the use of different processes, combining the clinical experiences with the preferences of the patient that is receiving the care, for the taking of decision of some specific problem.

\section{Final Considerations}

The making of this research, whose objective was to understand the perception of the nurses on the dimensions of the work they perform in the daily activities of a university hospital enabled them to unveil the reality which permeates the professional exercise of the nurse in this context. The results highlighted that the nurses who participated in this study perceived the development of their work link to other dimension, as follows: assistance, administrative, educative and of research, which is confirmed by the literature.

The first category represented the several meanings concerning the assistance dimension of the work of the nurse, characterized as the human care based on science and technology, articulated with systematized actions which require theoretical and practical knowledge in order to substantiate and enable the health professional for the development of the activities, once they are characterized by different levels of complexity.

In the administrative dimension of the work of the nurse, the indispensable role of this professional in managing care, material and human resources is highlighted, as well as the units of hospital organization, with the purpose of enabling and guaranteeing safe assistance to the health of the citizens and of the society.

The educative dimension of the work of the nurse focused him in a fundamental, driving and qualifying axis of the social practices, which enables an educational, effective and permanent process with the participation of everyone within the reach of common objectives.

Finally, the dimension of research in the work of the nurse points the need that the professional has of continuous updating to produce and consume results of the research, which subsidize the process of care.

Although the study presents limitations, once it is referring to the case of only one hospital, the results show that the nurses need to reflect more deeply on their own practices, in order to redirect their actions, overcome possible difficulties and adopt critical reflexive attitudes on the process of work as a whole.

The study of the aspects related to the process of work of the nurse is indispensable at all times, despite the fact that many researches have already approached this theme, once the elements of this process are rethought, serving as support to the facts already discovered or being discussed under a new focus, which can provide new perspective for Nursing. Directed to new or old discoveries it is worth highlighting that the most important thing in this course is 'to weave' the identity of the nurse, many times overshadowed by the overload of work even by the organizational interests. To know the process of work of the nurse is to contribute with the strengthening of the profession and also to glimpse new processes of work.

\section{Collaborations}

Presotto GV and Simões ALA contributed for the conception, organization and interpretation for the data and writing of the article. Ferreira MBG and Contim D contributed for the analysis, interpretation of data and writing of the article. 


\section{References}

1. Antunes R. A dialética do trabalho. São Paulo: Expressão Popular; 2004.

2. Hausmann M, Peduzzi M. Articulação entre as dimensões gerencial e assistencial do processo de trabalho do enfermeiro. Texto Contexto Enferm. 2009; 18(2):258-65.

3. Felli VEA, Peduzzi M. O trabalho gerencial em enfermagem. In: Kurcgant $P$, coordenadora. Gerenciamento em enfermagem. 2 ${ }^{\underline{a}}$ ed. Rio de Janeiro: Guanabara Koogan; 2012. p. 1-12.

4. Christovam BP, Porto IS, Oliveira DC. Nursing care management in hospital settings: the building of a construct. Rev Esc Enferm USP. 2012; 46(3):73441.

5. Almeida ML, Segui MLH, Maftum MA, Labronici LM, Peres AM. Instrumentos gerenciais utilizados na tomada de decisão do enfermeiro no contexto hospitalar. Texto Contexto Enferm. 2011; 20(Esp):131-7.

6. Kajermo NK, Bostrom AM, Thompson DS, Hutchinson AM, Estabrooks CA, Wallin L. The BARRIERS Scale - the barriers to research utilization scale: a systematic review. Implement Sci. 2010; 5:32.

7. Conselho Federal de Enfermagem (BR). Lei n. 7498/86, de 26 de junho de 1986. Dispõe sobre a regulamentação do exercício da enfermagem e dá outras providências. Diário Oficial da União, Brasília (DF); 26 jun 1986; Seção 1:9273-5.

8. Fontanella BJB, Luchesi BM, Saidel MGB, Ricas J, Turato ER, Melo DG. Sampling in qualitative research: a proposal for procedures to detect theoretical saturation. Cad Saúde Pública. 2011; 27(2):389-94.

9. Bardin L. Análise de conteúdo. Lisboa: Edições 70; 2009.

10. Giordani JN, Bisogno SBC, Silva LAA. Perception of nurses regarding management activities for user assistance. Acta Paul Enferm. 2012; 25(4):511-6.

11. Montezeli JH, Peres AM. Competência gerencial do enfermeiro: conhecimento publicado em periódicos brasileiros. Cogitare Enferm. 2009; 14(3):553-8.
12. Casafus KCU, Dell'acqua MCQ Bocchi SCM. Entre o êxito e a frustração com a sistematização da assistência de enfermagem. Esc Anna Nery. 2013; 17(2):313-21.

13. Brasil. Conselho Federal de Enfermagem. Resolução COFEN n. 272, de 27 de agosto de 2002. Disponível em: URL: htttp://www.portalcofen.com. br/_novo portal.

14. Oliveira APC, Coelho MEAA, Almeida VCF, Lisboa KWSC, Macêdo ALS. Systematization of nursing assistance: implementation in an intensive care unit. Rev Rene. 2012; 13(3):601-12.

15. Santos JLG, Pestana AL, Guerrero P, Meirelles BSH, Erdmann AL. Práticas de enfermeiros na gerência do cuidado em enfermagem e saúde: revisão integrativa. Rev Bras Enferm. 2013; 66(2):257-63.

16. Santos JLG, Lima MADS. Gerenciamento do cuidado: ações dos enfermeiros em um serviço hospitalar de emergência. Rev Gaúcha Enferm. 2011; 32(4):695-702.

17. Souza, MFG, Santos ADB, Monteiro AI. O processo de enfermagem na concepção de profissionais de Enfermagem de um hospital de ensino. Rev Bras Enferm. 2013; 66(2):167-73.

18. Santos JLG, Prochnow AG, Silva DC, Silva RM, Leite JL, Erdmann AL. Prazer e sofrimento no exercício gerencial do enfermeiro no contexto hospitalar. Esc Anna Nery. 2013; 17(1):97-103.

19. Zuliani LL, Jerico MC, Castro LC, Soler ZASG. Consumo e custo de recursos materiais em unidades pediátricas de terapia intensiva e semiintensiva. Rev Bras Enferm. 2012; 65(6):969-76.

20. Fernandes MCP, Backes VMS. Education in health: perspectives of the Family Health Strategy team under Paulo Freire's view. Rev Bras Enferm. 2010; 63(4):567-73.

21. Torres HC, Pereira FRL, Alexandre LR. Evaluation of the educational practices in promoting selfmanagement in type 2 diabetes mellitus. Rev Esc Enferm USP. 2011; 45(5):1077-82.

22. Silva GM, Seiffert OMLB. Educação Continuada em Enfermagem: uma proposta metodológica. Rev Bras Enferm. 2009; 62(3):362-6. 
23. Pires D. A enfermagem enquanto disciplina, profissão e trabalho. Rev Bras Enferm. 2009; 62(5):739-44.

24. Edward KL, Mills C. A hospital nursing research enhancement model. J Contin Educ Nurs. 2013; 44(10):1-8.
25. Melnyk BM, Fineout-Overholt E, Gallagher-Ford L, Kaplan L. The state of evidence-based practice in US Nurses. J Nurs Adm. 2012; 42(9):410-7. 